\title{
OPTIMASI MODEL SEGMENTASI CITRA METODE FUZZY DIVERGENCE PADA CITRA LUKA KRONIS MENGGUNAKAN ALGORITMA GENETIKA
}

\author{
Ghenniy Rachmansyah ${ }^{1}$, Wayan Firdaus Mahmudy ${ }^{2}$, Rizal Setya Perdana ${ }^{3}$ \\ 1,2,3 Fakultas Ilmu Komputer, Universitas Brawijaya, Malang \\ Email: ${ }^{1} 125150201111040 @$ mail.ub.ac.id, ${ }^{2}$ wayanfm@ub.ac.id, ${ }^{3}$ rizalespe@ub.ac.id
}

\begin{abstract}
Abstrak
Luka kronis merupakan masalah yang masih terbilang berat dalam penanganan, memerlukan ketekunan, biaya mahal, tenaga terlatih dan terampil. Proses pengkajian luka masih dilakukan secara manual, membutuhkan waktu yang cukup lama dan menghasilkan hasil yang lebih subyektif. Dengan adanya permasalahan tersebut, maka dibutuhkan sistem yang dapat membantu pengkajian luka dengan pendekatan citra digital atau dikenal dengan istilah digital planimetry. Fokus permasalahan yang diselesaikan hanya sebatas pada penggolongan komposisi jaringan luka dengan pendekatan segmentasi citra. Pada task segmentasi citra, algoritma yang digunakan yaitu fuzzy divergence yang dioptimasi menggunakan algoritma genetika untuk pemilihan nilai threshold optimal. Pada algoritma genetika, representasi kromosom berupa real-coded, proses reproduksi meliputi operasi extended intermediate crossover dan random mutation, serta metode seleksi elit dengan penambahan mekanisme random injection. Metode yang diusulkan dapat digunakan untuk mengoptimasi model segmentasi citra multilevel thresholding dengan meminimalkan nilai fuzzy divergence dengan parameter algoritma genetika; meliputi ukuran populasi sebesar 60, kombinasi ukuran $c r$ dan $m r$ secara berturut-turut 0.6 dan 0.4, dan ukuran generasi sebesar 100. Kemudian, berdasarkan evaluasi hasil segmentasi citra menggunakan Standar Deviasi (SD), distribusi Gamma menghasilkan hasil segmentasi yang lebih baik.
\end{abstract}

Kata kunci: luka kronis, digital planimetry, segmentasi citra, fuzzy divergence, algoritma genetika

\begin{abstract}
Chronic wounds are a problem that is still difficult in wound management, require persistence, high cost for treatment, and trained-skilled personnel. In wound management, the assessment process are still performed manually, however it's very time-consuming and produce more subjective outcomes. Given these problems, there is a need for a system that helps wound assessment with the approach in measuring wound size using digital images, known as digital planimetry. In this work, the focus only on wound tissue classification using image segmentation. In image segmentation, the algorithm used is fuzzy divergence that optimized by using genetic algorithm for selecting optimal threshold. For genetic algorithm, the representation of chromosomes is realcoded, then reproduction process using the extended intermediate crossover and random mutation, and elitism selection with the addition of random injection mechanism. The proposed method can use to optimize image segmentation multilevel thresholding by minimizing the value of fuzzy divergence with genetic algorithm parameters which includes the size of the population is 60, the combination of size Cr and Mr respectively 0.6 and 0.4, and the size of generation is 100. Then, based on the evaluation result of image segmentation using Standard Deviation (SD), found that Gamma distribution leads better segmentation as compared to others.
\end{abstract}

Keywords: chronic wounds, digital planimetry, image segmentation, fuzzy divergence, genetic algorithm

\section{PENDAHULUAN}

Menurut definisi dari Centers for Medicare and Medicaid Services, suatu luka dikatakan sebagai luka kronis (chronic wound), jika luka tersebut tidak sembuh dalam waktu 30 hari (Fauzi, et al., 2015). Secara global, luka kronis menjadi salah satu ancaman utama kesehatan dan ekonomi masyarakat, dimana menyebabkan depresi bagi penderita, pemisahan sosial, dan perawatannya yang membutuhkan biaya mahal (Mukherjee, et al., 2014). Tiga jenis luka yang dianggap sebagai luka kronis utama, yaitu luka kaki diabetik (diabetic foot ulcer), luka vena (venous ulcer), dan luka tekan (pressure ulcer). Ketiga jenis luka kronis ini yang rentan dan memerlukan perawatan medis jangka panjang (Mukherjee, et al., 2014). Di Indonesia, luka kronis masih merupakan masalah yang masih terbilang berat dalam penanganan baik dalam perawatan maupun rehabilitasinya yang masih sukar dan memerlukan ketekunan, biaya mahal, tenaga terlatih dan terampil.

Dalam hal penanganan luka kronis, proses pengkajian luka masih dilakukan secara manual yang prosesnya membutuhkan waktu yang cukup lama dan menghasilkan suatu hasil yang lebih subyektif (Fauzi, et al., 2015). Dengan adanya permasalahan tersebut, dibutuhkan sebuah sistem yang membantu dalam pengkajian luka, meliputi 
penggolongan komposisi jaringan luka, pengukuran daerah luka atau wound size, dan memonitor perubahan yg terjadi pada luka. Pendekatan dalam pengukuran luka (wound size) menggunakan citra digital, dikenal dengan istilah digital planimetry, yang mengidentifikasi batas luka dan jenis jaringan luka berdasarkan citra atau gambar. Dalam penelitian kali ini, fokus permasalahan yang akan diselesaikan hanya sebatas pada penggolongan komposisi jaringan luka dengan pendekatan segmentasi citra.

Penelitian berkaitan dengan wound assessment yang dilakukan oleh Mukherjee et al. (2014) mengenai klasifikasi jaringan luka pada luka kronis yang meliputi granulasi (granulation), nekrotik (necrotic) dan slough. Pada segmentasi, digunakan metode fuzzy divergence, selanjutnya teknik machine learning digunakan untuk mengklasifikasikan jaringan luka, yaitu Support Vector Machine (SVM) dan Bayesian. Berdasarkan hasil pengujian, metode yang diusulkan menghasilkan akurasi tertinggi sebesar $87.61 \%$.

Kemudian, penelitian terkait segmentasi citra dilakukan oleh Chaira et al. (2003) yang mengusulkan teknik thresholding menggunakan fuzzy divergence. Untuk menentukan fungsi keanggotaan dari setiap nilai piksel pada citra digunakan distribusi Gamma (Gamma distribution). Teknik thresholding ini dilakukan dengan tujuan untuk memilih nilai threshold optimal untuk mengekstraksi objek dengan meminimumkan nilai fuzzy divergence. Pengujian terhadap unilevel, bilevel, dan multilevel thresholding menunjukkan hasil yang memuaskan. Teknik fuzzy divergence juga digunakan dalam task segmentasi citra medis, yaitu mikroskopis sel darah merah (Ghosh, et al., 2010; Ghosh, 2013; Jati, et al., 2015).

Penelitian terkait penggunaan algoritma evolusi dalam segmentasi citra cukup banyak dilakukan oleh beberapa peneliti. Salah satunya penelitian yang dilakukan oleh Manikandan et al. (2013) mengenai multilevel thresholding segmentasi citra MRI otak menggunakan algoritma genetika dengan representasi real coded.

Berdasarkan pemaparan dari penelitian sebelumnya, maka diusulkan penelitian menggunakan algoritma genetika untuk mengoptimasi nilai threshold pada segmentasi citra luka kronis dengan meminimalkan nilai fuzzy divergence. Dengan demikian, metode yang diusulkan diharapkan dapat digunakan dan dikembangkan lebih lanjut dalam task pengukuran daerah luka berdasarkan penggolongan komposisi jaringan luka dengan penilaian yang lebih akurat.

\section{RUANG LINGKUP PERMASALAHAN}

Untuk menghindari dari melebarnya permasalahan, maka ruang lingkup permasalahan yang coba diselesaikan adalah sebagai berikut:
1. Data yang digunakan merupakan data citra luka sekunder yang diperoleh dari Medetec Wound

Database (http://www.medetec.co.uk).

2. Untuk data citra luka yang digunakan, daerah luka yang akan disegmentasi, terdiri dari 3 sampai 4 komposisi jaringan, yaitu granulasi (granulation), nekrotik (necrotic), slough, dan epitelialisasi.

3. Pada teknik thresholding fuzzy divergence, fungsi keanggotaan dari setiap piksel citra digunakan distribusi Gamma, Gaussian, dan Cauchy.

4. Metode yang digunakan dalam penelitian ini adalah algoritma genetika untuk meminimumkan nilai fuzzy divergence.

\section{DASAR TEORI}

\subsection{Luka Kronis (Chronic Wounds)}

Menurut definisi dari Centers for Medicare and Medicaid Services, suatu luka dikatakan sebagai luka kronis (chronic wound), jika luka tersebut tidak sembuh dalam waktu 30 hari (Fauzi, et al., 2015). Luka kronis merupakan sebuah luka yang tidak melanjutkan proses reparatif secara tertib dan berkala untuk menghasilkan integritas anatomi dan fungsional dari luka tersebut, umumnya tidak sembuh selama lebih dari 6 minggu. Penyembuhan juga mungkin tertunda jika perawatan yang tepat tidak diberikan berdasarkan diagnosis yang akurat (Mukherjee, et al., 2014).

Sebuah luka menunjukkan struktur yang kompleks dan mungkin terdiri dari berbagai jenis jaringan luka (wound tissue), seperti granulasi (granulation), slough, eschar atau nekrotik (necrotic), epitelisasi (epithelialization), tulang, tendon, dan pembuluh darah, masing-masing dengan karakteristik warna dan tekstur yang berbeda (Fauzi, et al., 2015; Mukherjee, et al., 2014). Sedangkan jenis jaringan yang paling sering terlihat dalam suatu luka, yaitu granulasi, slough, dan eschar seperti yang ditunjukkan pada Gambar 1 .
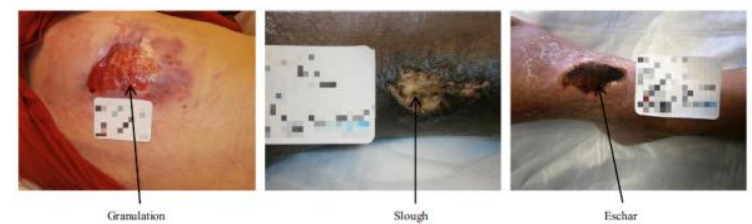

Gambar 1. Jenis Jaringan Luka (Wound Tissue) Sumber: Fauzi, et al. (2015)

\subsection{Segmentasi Citra}

Segmentasi citra merupakan task dan proses mendasar dalam computer vision dan aplikasi pemrosesan citra (Ren, 2009; Wei, 2010). Segmentasi citra merujuk pada prosedur untuk membagi atau menggolongkan citra menjadi beberapa segmen, region atau objek sesuai dengan kesamaan karakteristik atau fitur, seperti warna, tekstur, dan kecerahan (Jati, et al., 2015; Muppidi, et 
al., 2015; Pare, et al., 2015). Segmentasi juga biasa digunakan untuk mengidentifikasi region of interest (ROI) atau informasi lain yang relevan dalam citra digital (Salavati, 2015). Dalam aplikasinya, segmentasi banyak digunakan dalam pengolahan dan analisis citra pada citra medis (Jati, et al., 2015), seperti citra retina (Putra, 2010), citra CT kepala (head CT image); MRI otak (Wei, 2010; Manikandan, et al., 2013), citra mikroskopis sel darah merah (Ghosh, et al., 2010; Ghosh, 2013), dan citra luka kronis (Mukherjee, et al., 2014; Fauzi, et al., 2015).

\subsection{Image Thresholding Fuzzy Divergence}

Metode yang popular, efektif, dan tergolong sederhana jika dibandingkan dengan metode lainnya, yaitu metode thresholding yang membagi atau memisahkan citra menjadi beberapa segmen berdasarkan nilai threshold (Hammouche, 2007; Ren, 2009; Manikandan, et al., 2013; Sridevi, et al., 2014; Pare, et al., 2015; Salavati, 2015).

Sebuah metode baru image thresholding diusulkan yaitu mengenai penggunaan metode fuzzy divergence untuk segmentasi citra (Chaira, 2003; Ghosh, et al., 2010; Bhatia, 2013; Ghosh, 2013; Jati, et al., 2015). Suatu teori himpunan fuzzy digunakan pada image thresholding untuk memisahkan atau membagi citra ke dalam beberapa segmen atau daerah (Chaira, 2003; Bhatia, 2013). Penerapan fuzzy pada pemrosesan citra dikarenakan beberapa alasan, seperti imprecision dari graylevel suatu citra; ambiguitas dari beberapa definisi, seperti batas atau boundary antar daerah (region) suatu citra.

\subsubsection{Fuzzy Image dan Fungsi Keanggotaan}

Misalkan $A$ adalah sebuah citra dengan ukuran $M x N$ dengan $L$ gray level, maka kombinasi antara nilai dari gray level dan keanggotaan $\mu\left(f_{i j}\right)$ dari piksel $(i, j)$ didefinisikan pada Persamaan (1) berikut (Chaira, 2003; Ghosh, et al., 2010; Bhatia, 2013; Ghosh, 2013; Jati, et al., 2015).

$A=\left\{f_{i j}, \mu\left(f_{i j}\right)\right\}, \forall f_{i j} \in A ;$ dimana $0 \leq \mu\left(f_{i j}\right) \leq 1$ (1)

Kemudian, untuk nilai threshold $t$ yang akan membagi citra menjadi objek dan background. Nilai rataan (mean) gray level dari background $\left(\mu_{0}\right)$ dan objek $\left(\mu_{1}\right)$ didefinisikan pada Persamaan (2) berikut (Chaira, 2003; Ghosh, et al., 2010; Bhatia, 2013; Ghosh, 2013).

$\mu_{0}=\frac{\sum_{f=0}^{t} f . \operatorname{count}(f)}{\sum_{f=0}^{t} \operatorname{count}(f)} ; \mu_{1}=\frac{\sum_{f=t+1}^{L-1} f \cdot \operatorname{count}(f)}{\sum_{f=t+1}^{L-1} \operatorname{count}(f)}$

Untuk nilai keanggotaan dari tiap piksel ditentukan menggunakan distribusi Gamma, Gaussian, dan Cauchy yang akan dijelaskan pada sub-bab berikut.

\subsubsection{Distribusi Gamma}

Secara umum, fungsi distribusi Gamma didefinisikan pada Persamaan (3) berikut (Chaira, 2003; Ghosh, et al., 2010; Bhatia, 2013; Ghosh, 2013; Jati, et al., 2015). $f(x)=\frac{\left(\frac{(x-v)}{\beta}\right)^{\gamma-1} \exp \left(-\frac{(x-v)}{\beta}\right)}{\Gamma(\gamma)}, x \geq v, \gamma, \beta>0$

Dimana $\gamma$ adalah parameter shape, $v$ adalah parameter lokasi, $\beta$ adalah parameter scale dan $\Gamma$ adalah fungsi Gamma yang didefinisikan Persamaan (4) berikut.

$\Gamma(\gamma)=\int_{0}^{\infty} u^{\gamma-1} e^{-u} d u$

Kemudian pada kasus $v=0$ dan $\beta=1$, maka distribusi Gamma didefinisikan pada Persamaan (5) berikut yang dikenal dengan standar distribusi Gamma.

$f(x)=\frac{(x)^{\gamma-1} \exp (-x)}{\Gamma(\gamma)}, x \geq 0, \gamma>0$

Pada kasus $v \neq 0$ dan $\beta=1$ dan $\gamma=1$, maka distribusi Gamma didefinisikan pada Persamaan (6) berikut.

$f(x)=\exp (-(x-v))$

Dari Persamaan (6), maka fungsi keanggotaan $\mu\left(f_{i j}\right)$ untuk daerah objek dan background dihitung menggunakan Persamaan (7) berikut.

$f(x)=\left\{\begin{array}{lr}\exp \left(-c \cdot\left|f_{i j}-\mu_{0}\right|\right) & \text { jika } f_{i j} \leq t, \text { untuk background } \\ \exp \left(-c \cdot\left|f_{i j}-\mu_{1}\right|\right) & \text { jika } f_{i j}>t, \text { untuk objek }\end{array}\right.$

Dimana $t$ adalah sembarang nilai threshold dan konstanta c digunakan agar nilai keanggotaan tetap pada range $[0,1]$ yang didefinisikan pada Persamaan (8) berikut.

$c=\frac{1}{\left(f_{\max }-f_{\min }\right)}$

dimana $f_{\max }$ dan $f_{\min }$ adalah nilai maksimum dan minimum gray level dari citra.

\subsubsection{Distribusi Gaussian}

Secara umum, fungsi distribusi Gaussian didefinisikan pada Persamaan (9) berikut (Ghosh, et al., 2010; Jati, et al., 2015).

$f(x)=\exp \left(-\frac{(x-b)^{2}}{2 \sigma^{2}}\right), x \geq b, \sigma>0$

Dimana $\sigma$ adalah parameter scale dan $b$ adalah parameter lokasi. Pada kasus $\sigma=1$, maka fungsi keanggotaan $\mu\left(f_{i j}\right)$ untuk daerah objek dan background dihitung menggunakan Persamaan (10) berikut.

$$
f(x)=\left\{\begin{array}{lr}
\exp \left(-A \cdot\left|f_{i j}-\mu_{0}\right|\right) & j i k a \\
\exp \left(-A \cdot\left|f_{i j} \leq t, \mu_{1}\right|\right) & \text { jika } f_{i j}>t, \text { untuk background }
\end{array}\right.
$$

Dimana $t$ adalah sembarang nilai threshold dan konstanta $A$ didefinisikan sebagai $c / 2$.

\subsubsection{Distribusi Cauchy}

Secara umum, fungsi distribusi Cauchy didefinisikan pada Persamaan (11) berikut (Ghosh, et al., 2010; Ghosh, 2013; Jati, et al., 2015).

$$
f\left(x, x_{0}, \gamma\right)=\frac{1}{\pi \gamma\left[1+\left(\left(\frac{x-x_{0}}{\gamma}\right)^{2}\right)\right]}, x>x_{0}, \gamma>0
$$

Dimana $\gamma$ adalah parameter scale dan $x_{0}$ adalah parameter lokasi. Pada kasus $\gamma=1$, maka fungsi keanggotaan $\mu\left(f_{i j}\right)$ untuk daerah objek dan 
background dihitung menggunakan Persamaan (12) berikut.

$f(x)=\left\{\begin{array}{l}B\left[\frac{1}{1+\left(f_{i j}-\mu_{0}\right)^{2}}\right] \\ B\left[\frac{1}{1+\left(f_{i j}-\mu_{1}\right)^{2}}\right] \quad \text { jika } f_{i j} \leq t, \text { untuk background } f_{i j}>t, \text { untuk objek }\end{array}\right.$

Dimana $t$ adalah sembarang nilai threshold dan konstanta $B$ didefinisikan sebagai $c / \pi$.

\subsubsection{Fuzzy Divergence}

Sebuah citra $A$ dengan ukuran $M x M$ dengan $L$ graylevel, maka fuzzy entropy dari citra $A$ didefinisikan sebagai berikut (Chaira, 2003; Ghosh, et al., 2010; Mukherjee, et al., 2014).

$H(A)=\frac{1}{n(\sqrt{e}-1)} \sum_{i-0}^{M-1} \sum_{j-0}^{M-1}\left[\left(\mu_{A} f_{i j}\right) \cdot e^{1-\mu_{A} f_{i j}}+\left(1-\mu_{A} f_{i j}\right) \cdot e^{\mu_{A} f_{i j}}-1\right]$

Dimana $n=M^{2}$ dan $i, j=0,1,2, \ldots,(M-1), \mu_{A} f_{i j}$ adalah nilai keanggotaan piksel ke (i,j) dari citra $A$.

Untuk 2 citra, yaitu $A$ dan $B$, informasi diskriminasi antara $\mu_{A} f_{i j}$ dan $\mu_{B} f_{i j}$ dari kedua citra tersebut didefinisikan sebagai berikut (Chaira, 2003; Ghosh, et al., 2010; Mukherjee, et al., 2014).

$e^{\mu_{A} f_{i j}} / e^{\mu_{B} f_{i j}}=e^{\mu_{A} f_{i j}-\mu_{B} f_{i j}}$

Diskriminasi antara citra A dan B; sebaliknya diskriminasi antara citra B dan A didefinisikan pada Persamaan (15) berikut (Chaira, 2003; Ghosh, et al., 2010; Mukherjee, et al., 2014).

$D_{1}(A, B)=\sum_{i-0}^{M-1} \sum_{j-0}^{M-1}\left[1-\left(\left(1-\mu_{A} f_{i j}\right) \cdot e^{\mu_{A} f_{i j}-\mu_{B} f_{i j}}\right)-\left(\mu_{A} f_{i j} \cdot e^{\mu_{B} f_{i j}-\mu_{A} f_{i j}}\right)\right]$
$D_{2}(B, A)=\sum_{i-0}^{M-1} \sum_{j-0}^{M-1}\left[1-\left(\left(1-\mu_{B} f_{i j}\right) \cdot e^{\mu_{B} f_{i j}-\mu_{A} f_{i j}}\right)-\left(\mu_{B} f_{i j} \cdot e^{\mu_{A} f_{i j}-\mu_{B} f_{i j}}\right)\right]$

Jadi, total fuzzy divergence antara citra $A$ dan $B$ adalah sebagai berikut.

$D(A, B)=D_{1}(A, B)+D_{2}(A, B)$

$$
\begin{aligned}
= & \sum_{i-0}^{M-1} \sum_{j-0}^{M-1}\left[2-\left(\left(1-\mu_{A} f_{i j}+\mu_{B} f_{i j}\right) \cdot e^{\mu_{A} f_{i j}-\mu_{B} f_{i j}}\right)-\left(1-\mu_{B} f_{i j}+\right.\right. \\
& \left.\left.\left.\mu_{A} f_{i j}\right) \cdot e^{\mu_{B} f_{i j}-\mu_{A} f_{i j}}\right)\right]
\end{aligned}
$$

\subsection{Algoritma Genetika}

Dalam menyelesaikan suatu masalah, tiap alternatif solusi harus dipetakan dalam bentuk kromosom (chromosome) yang tersusun atas sejumlah gen yang merepresentasikan sejumlah variabel keputusan yang digunakan dalam solusi tersebut. Tiap solusi akan dievaluasi dengan fungsi fitness. Algoritma genetika dengan mekanisme penurunan sifat dan seleksi alam akan menghasilkan sebuah solusi dengan kromosom terbaik setelah generasi ke- $n$. Kromosom yang merepresentasikan sebuah solusi atau individu harus diuraikan (decoding) menjadi solusi yang diharapkan (Ren, 2009; Wei, 2010; Mahmudy, 2014; Wijayaningrum \& Mahmudy, 2016, Salavati, 2015).

Secara umum, algoritma genetika memiliki 5 komponen berikut (Manikandan, et al., 2013):

1) Sebuah representasi dari solusi untuk suatu permasalahan tertentu.
2) Sebuah mekanisme untuk menginisialisasi populasi yang merepresentasikan beberapa alternatif solusi.

3) Fungsi evaluasi untuk mengevaluasi dan mengukur seberapa baik sebuah individu atau solusi, kaitannya dengan nilai fitness sebuah individu.

4) Mekanisme seleksi induk dan operator genetika atau reproduksi yang meliputi crossover dan mutasi.

5) Nilai untuk parameter algoritma genetika.

\section{METODOLOGI DAN PERANCANGAN}

\subsection{Data Penelitian}

Data terdiri dari data citra luka kronis yang terdiri dari luka venous dan arterial, luka penderita diabetes (diabetic ulcer), dan luka tekan (pressure ulcer) dengan format citra berupa JPEG (.jpg) dengan resolusi 96 dpi dan dimensi sebesar 560x367 piksel yang diperoleh dari Medetec Wound Database (http://www.medetec.co.uk). Sampel data citra disajikan pada Tabel 1.

Tabel 1. Sampel Data Citra Luka Kronis

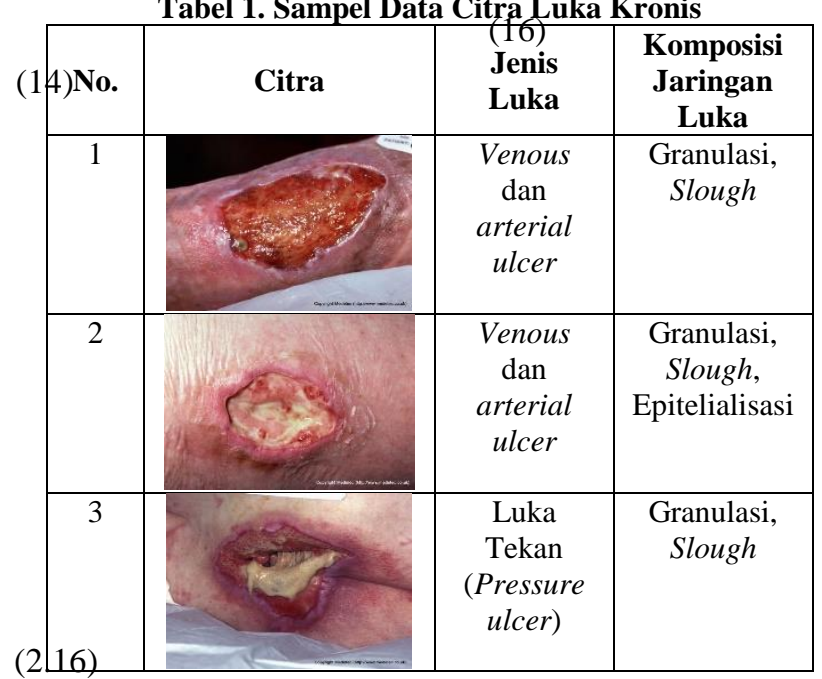

\subsection{Alur Sistem}

Sistem yang akan dikembangkan bertujuan untuk menyelesaikan permasalahan pada penggolongan komposisi jaringan luka berdasarkan citra luka menggunakan metode segmentasi citra fuzzy divergence. Pada kasus multilevel thresholding hasil segmentasi akan tergantung pada pemilihan nilai threshold yang merupakan permasalahan optimasi untuk mendapatkan solusi, berupa nilai optimal threshold. Penambahan algoritma genetika digunakan untuk mengoptimasi model segmentasi fuzzy divergence. Alur sistem secara keseluruhan digambarkan pada skema berikut (Gambar 2). 


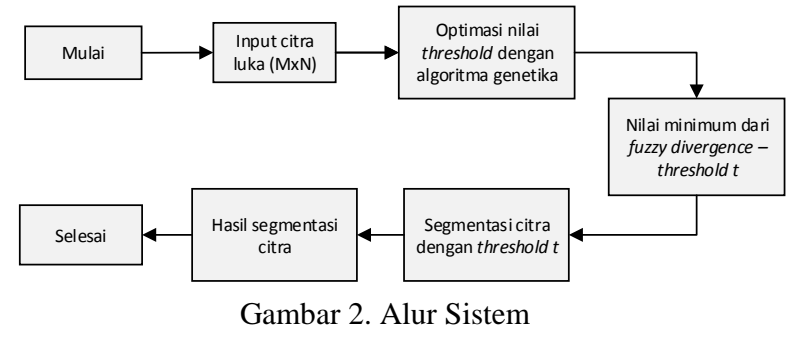

\subsection{Segmentasi Citra Fuzzy Divergence}

Penyelesaian segmentasi citra menggunakan fuzzy divergence dijelaskan pada diagram alur sebagai berikut (Gambar 3). Pada image thresholding, nilai keanggotan dari citra $A$ yang sudah disegmentasi dengan threshold $t$ dibandingkan dengan suatu citra yang secara ideal tersegmentasi yang didefinisikan sebagai citra dengan sejumlah daerah atau region yang secara total termasuk bagian dari masing-masing daerah yang terbentuk. Dengan kata lain, keanggotaan dari citra $B$ untuk tiap pikselnya pada tiap daerah atau region sama dengan 1, sehingga didapatkan nilai total fuzzy divergence. Persamaan (16) yang mendefinisikan nilai total fuzzy divergence diubah menjadi Persamaan (17) berikut.

$$
\begin{aligned}
D(A, B) & =D_{1}(A, B)+D_{2}(A, B) \\
& \left.=\sum_{i-0}^{M-1} \sum_{j-0}^{M-1}\left[2-\left(\left(2-\mu_{A} f_{i j}\right) \cdot e^{\mu_{A} f_{i j}-1}\right)-\left(\mu_{A} f_{i j}\right) \cdot e^{1-\mu_{A} f_{i j}}\right)\right]
\end{aligned}
$$

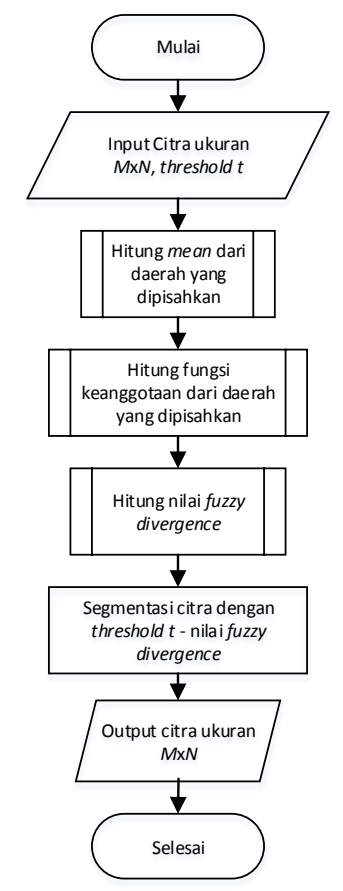

Gambar 3. Diagram Alur Segmentasi Citra Fuzzy Divergence

\subsection{Algoritma Genetika}

Pada multilevel thresholding dengan level $n$, maka untuk mendapatkan nilai threshold yang optimal, dibutuhkan sebuah pendekatan exhaustive search yang memungkinkan sejumlah kombinasi nilai threshold sebesar $n(L-n+1)^{n-1}$ kemungkinan untuk mengevaluasi nilai threshold (Ayala, et al., 2014). Dalam hal ini, digunakan algoritma genetika untuk mengoptimasi nilai multilevel threshold pada segmentasi citra luka dengan meminimalkan nilai fuzzy divergence.

Kromosom tersusun atas gen yang dibangkitkan secara acak dalam rentang $[0,1]$ yang merepresentasikan fitur warna citra dengan panjang gen kromosom sebesar $n$, tergantung pada jumlah nilai threshold $t$ yang digunakan untuk memisahkan daerah pada citra $A$ menjadi $t+1$ daerah. Ilustrasi representasi kromosom ditunjukkan pada Gambar 4.

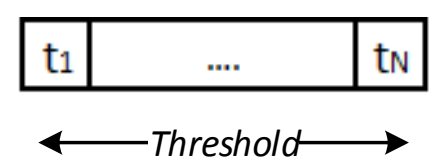

Dimana $t n<t n+1$

Gambar 4. Representasi Kromosom

Kemudian, untuk perhitungan fitness dihitung menggunakan metode segmentasi citra fuzzy divergence untuk mencari nilai fuzzy divergence minimum (Persamaan 17). Dalam permasalahan ini, tujuan yang ingin dicapai yaitu meminimalkan fungsi fuzzy divergence (D), maka perhitungan fitness untuk permasalahan minimasi dihitung menggunakan Persamaan (18) Sehingga semakin kecil nilai $D$, maka semakin besar nilai fitness.

Fitness $=\frac{100}{D}$

Proses reproduksi meliputi operasi extended intermediate crossover dan random mutation (Mahmudy, et al., 2013, Mahmudy \& Rahman, 2011). Kemudian, mekanisme seleksi menggunakan metode seleksi elitism yang hanya memilih (popSize-n) individu terbaik, sedangkan $n$ individu merupakan individu baru yang ditambahkan untuk menjaga keragaman individu dalam populasi dan juga untuk menghindari konvergensi dini atau dikenal dengan mekanisme random injection. Secara keseluruhan algoritma genetika digambarkan sebagai berikut (Gambar 5).

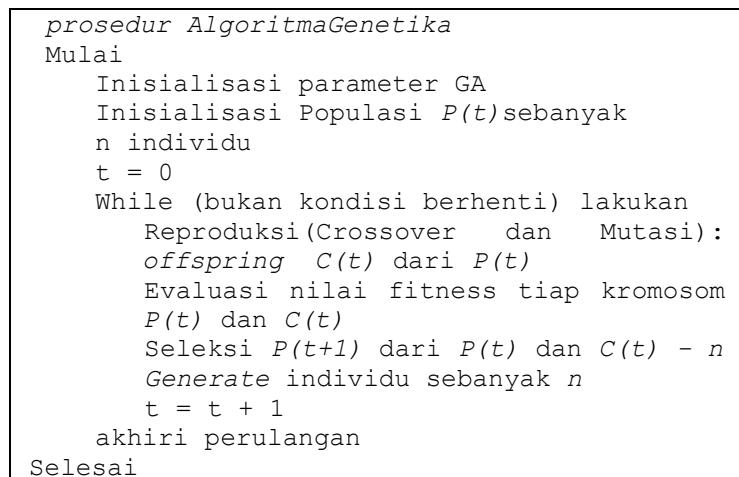

Gambar 5. Pseudocode Algoritma Genetika 


\section{PENGUJIAN DAN PEMBAHASAN}

\subsection{Pengujian Algoritma Genetika}

Pengujian algoritma genetika yang meliputi pengujian ukuran populasi (popSize), pengujian ukuran generasi, dan pengujian kombinasi ukuran crossover rate dan mutation rate. Pengujian algoritma menggunakan citra $A$ dengan ukuran $560 \times 367$ (Gambar 6) dengan 5 daerah atau segmen.

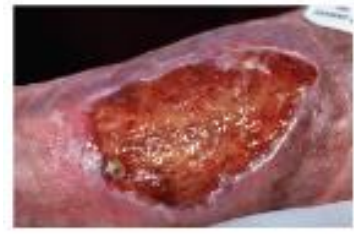

[s]

Gambar 6. Citra Uji

(a) Citra Uji A, (b) Citra Uji A' dalam Representasi Grayscale

\subsubsection{Pengujian dan Analisis Ukuran Populasi}

Pengujian ukuran populasi, dilakukan mulai dari ukuran 20 sampai 100 dengan kelipatan 20. Kemudian, dilakukan pada generasi 50 dan kombinasi ukuran crossover rate dan mutation rate, sebesar 0.6 dan 0.4 . Setiap pengujian dilakukan sebanyak 5 kali percobaan dan dihitung rata-rata nilai fitness-nya.

Pada grafik (Gambar 7) dapat dilihat bahwa semakin besar ukuran populasi, maka nilai rataan fitness juga semakin besar. Hal ini menunjukkan bahwa dengan ukuran populasi yang semakin besar, semakin beragam pula variasi individu yang dihasilkan dan semakin besar pula kemungkinan untuk mendapatkan solusi terbaik. Namun, tidak menutup kemungkinan pula bahwa nilai rataan fitness dapat berubah. Pada percobaan di atas, dapat disimpulkan bahwa jumlah atau ukuran populasi yang menghasilkan solusi mendekati optimal, yaitu 60. Ukuran populasi lebih besar dari 60 menghasilkan nilai fitnes yang cenderung naik, tetapi dengan selisih yang tidak signifikan.

\subsubsection{Pengujian dan Analisis Ukuran Crossover Rate dan Mutation Rate}

Pengujian kombinasi ukuran crossover rate dan mutation rate dilakukan pada ukuran populasi sebesar 60 dan generasi 50. Pada pengujian nilai $\mathrm{cr}$ dan $m r$ digunakan rentang nilai 0,1 sampai 0,9 . Setiap pengujian dilakukan sebanyak 5 kali percobaan dan dihitung rata-rata nilai fitness-nya.

Pada grafik (Gambar 8) dapat dilihat bahwa kombinasi ukuran crossover rate ( $\mathrm{cr}$ ) dan mutation rate $(\mathrm{mr})$ sangat mempengaruhi rata-rata nilai fitness kaitannya denga kemampuan eksplorasi dan eksploitasi yang seimbang [17]. Dalam grafik (Gambar 8) dapat dilihat, jika nilai $c r$ dan $m r$ yang digunakan terlalu rendah, maka rata-rata fitness yang dihasilkan pun tidak menghasilkan solusi yang lebih baik. Pada percobaan di atas, dapat disimpulkan bahwa kombinasi untuk nilai $c r$ dan $m r$ yang menghasilkan solusi mendekati optimal, yaitu 0.6 dan 0.4 .

\subsubsection{Pengujian dan Analisis Ukuran Generasi}

Pengujian dilakukan mulai dari ukuran 25 sampai 150 dengan kelipatan 25. Setiap pengujian dilakukan sebanyak 5 kali percobaan dan dihitung rata-rata nilai fitness-nya. Pada grafik (Gambar 9) dapat dilihat bahwa semakin besar ukuran generasi, maka nilai rataan fitness juga semakin besar. Hal ini menunjukkan bahwa ukuran generasi sangat berpengaruh pada rataan fitness yang dihasilkan karena semakin beragam pula variasi individu yang dihasilkan. Selain itu, dengan besarnya ukuran generasi, maka ruang pencarian atau eksplorasi algoritma genetika semakin luas. Pada grafik dapat dilihat bahwa pada generasi 50 dan 75, nilai rataan fitness cenderung stabil, walaupun terdapat sedikit peningkatan dan penurunan. Pada percobaan di atas, dapat disimpulkan bahwa jumlah atau ukuran generasi yang menghasilkan solusi mendekati optimal, yaitu 100. Ukuran populasi yang terlalu besar juga akan berpengaruh pada waktu komputasi yang semakin lama. Ukuran generasi lebih besar dari 100 menghasilkan nilai fitnes yang tetap, kondisi ini disebut dengan konvergensi.

\subsection{Hasil Segmentasi Fuzzy Divergence}

Berdasarkan parameter algoritma genetika terbaik, meliputi ukuran populasi $=60$, jumlah generasi $=100$, dan kombinasi nilai $\mathrm{cr}$ dan $\mathrm{mr}$ secara berturut-turut 0.6 dan 0.4 , kemudian diterapkan multilevel thresholding untuk memisahkan daerah pada citra A (Gambar 5) menjadi 5 daerah atau segmen. Dari hasil decoding kromosom dari individu terbaik, maka berikut merupakan hasil citra output A' yang sudah tersegmentasi ditunjukkan pada Gambar 10.

Berdasarkan solusi terbaik algoritma genetika, hasil segmentasi fuzzy divergence (Gambar 10) yang dihasilkan masih belum bisa memisahkan atau menggolongkan komposisi jaringan luka. Hal ini terjadi disebabkan oleh beberapa faktor, diantaranya representasi warna yang digunakan pada citra. Representasi warna yang digunakan akan berpengaruh pada nilai piksel atau fitur yang akan dipisahkan atau disegmentasi menjadi beberapa segmen. Kemudian, luka kronis juga merupakan objek yang sulit untuk dipisahkan, terutama untuk daerah luka dan daerah non-luka yang memiliki komposisi warna yang hampir sama. Untuk menggolongkan komposisi jaringan luka, perlu ditambahkan sebuah metode atau mekanisme yang memisahkan daerah luka dan daerah non-luka terlebih dahulu. Namun, secara umum sistem dapat menghasilkan solusi berupa nilai threshold optimal dengan parameter nilai minimum fuzzy divergence. 
72 Jurnal Teknologi Informasi dan Ilmu Komputer (JTIIK), Vol. 3, No. 1, Maret 2016, hlm. 66-74
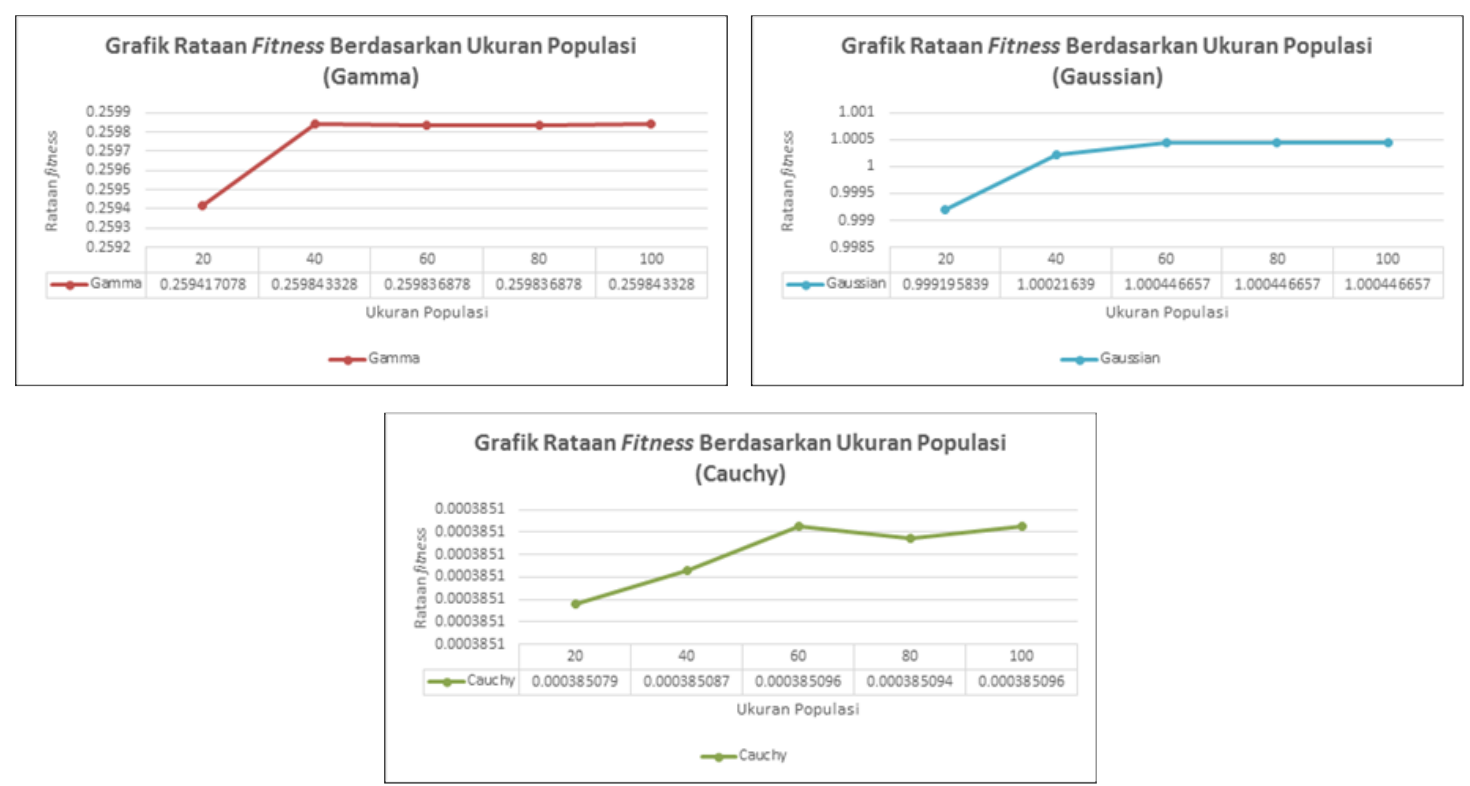

Gambar 7. Grafik Rataan Fitness Berdasarkan Ukuran Populasi
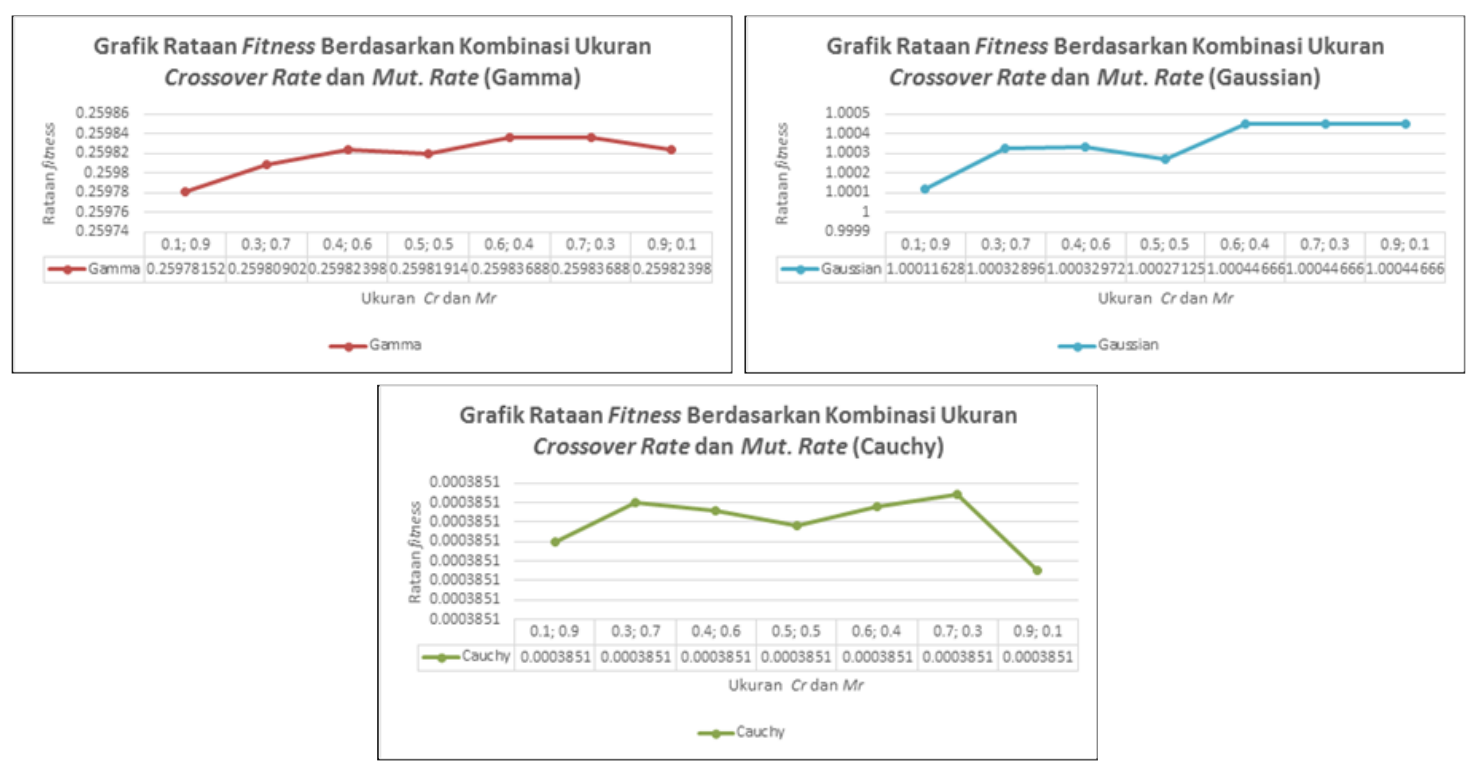

Gambar 8. Grafik Rataan Fitness Berdasarkan Kombinasi Ukuran $\mathrm{Cr}$ dan $\mathrm{Mr}$

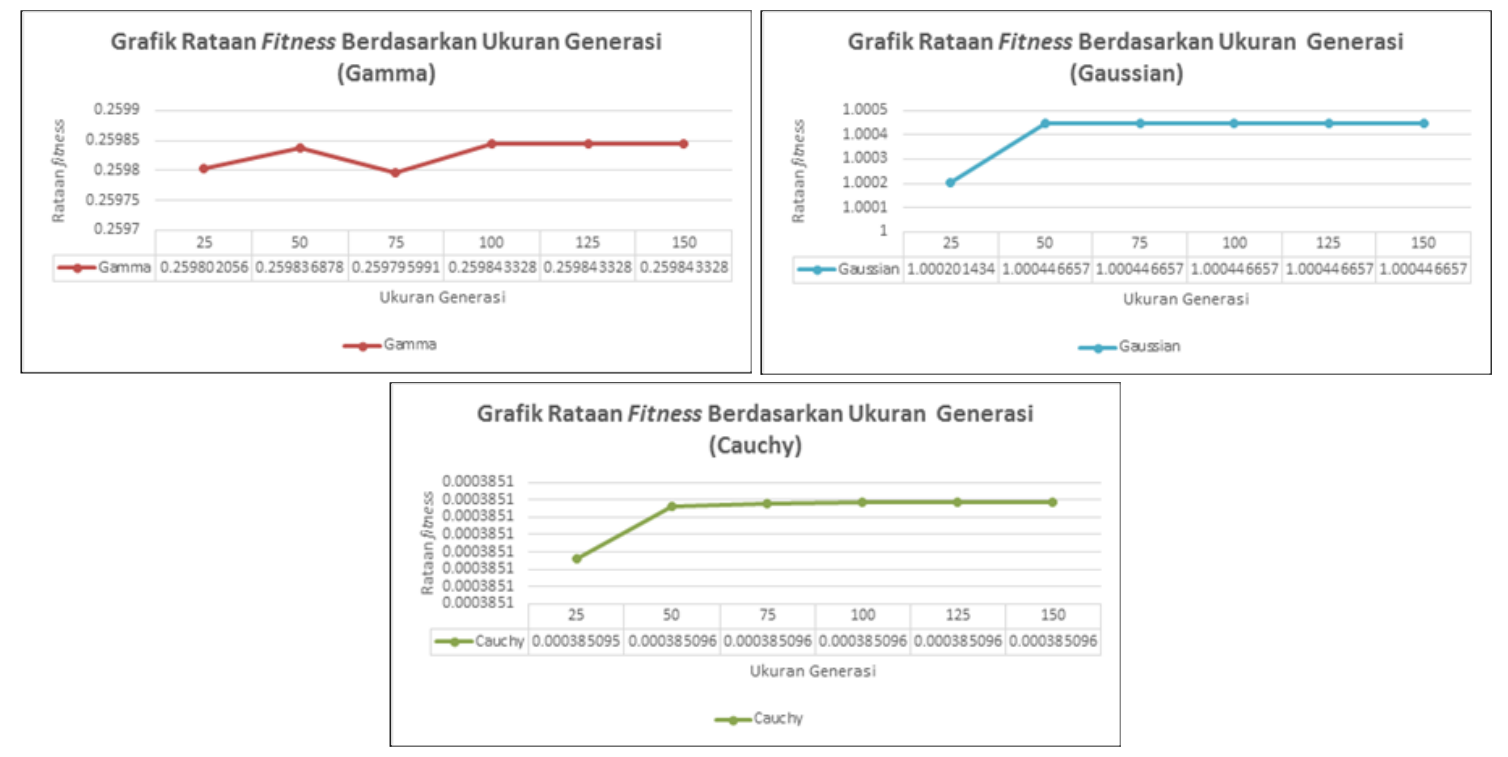




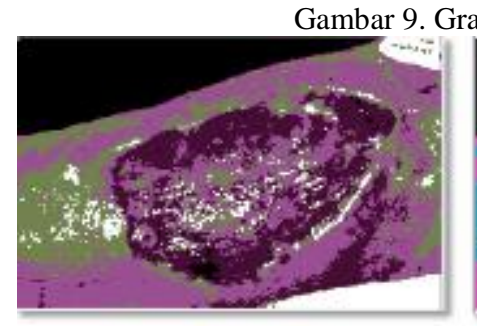

(a)

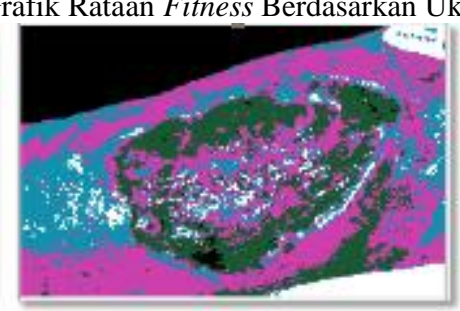

(b)

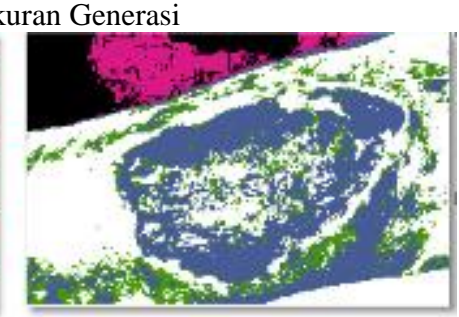

(c)

Gambar 10. Hasil Segmentasi Citra Berdasarkan Parameter Algoritma Genetika Terbaik

(a) Citra Output (Distribusi Gamma), (b) Citra Output (Distribusi Gaussian), Citra Output (Distribusi Cauchy)

\subsection{Pengujian Segmentasi Fuzzy Divergence}

Pada sub bab ini akan dibahas mengenai pengujian terkait hasil segmentasi citra menggunakan fuzzy divergence. Berdasarkan parameter algoritma genetika terbaik, akan dilakukan pengujian terhadap distribusi yang digunakan untuk membentuk fungsi keanggotaan citra, meliputi distribusi Gamma, Gaussian, dan Cauchy. Hasil pengujian segmentasi citra ditunjukkan pada Tabel 2 berikut.

Tabel 2. Hasil Pengujian Segmentasi Citra

\begin{tabular}{|c|c|c|c|c|c|c|c|}
\hline \multirow{2}{*}{$\begin{array}{l}\text { Cit- } \\
\text { ra }\end{array}$} & \multirow{2}{*}{ Level } & \multicolumn{3}{|c|}{ Nilai Threshold } & \multicolumn{3}{|c|}{ Standar Dev. } \\
\hline & & Gamma & Gaussian & Cauchy & Gamma & Gaussian & Cauchy \\
\hline \multirow[b]{2}{*}{1} & 4 & $\begin{array}{c}37,84, \\
118,164]\end{array}$ & $\begin{array}{c}{[37,84,} \\
119,165]\end{array}$ & $\begin{array}{c}{[7,10,} \\
95,106]\end{array}$ & 10.5166 & 10.6122 & 18.4893 \\
\hline & 5 & $\begin{array}{c}34,76, \\
102,128,1 \\
69]\end{array}$ & $\begin{array}{c}{[34,76,} \\
102,129,1 \\
70]\end{array}$ & $\begin{array}{c}{[7,11,} \\
93,104,111]\end{array}$ & 8.64575 & 8.67325 & 16.1324 \\
\hline 2 & 4 & $\begin{array}{l}993,127, \\
161,197]\end{array}$ & $\begin{array}{l}{[92,126,} \\
160,197]\end{array}$ & $\begin{array}{c}{[128,144,} \\
153,164]\end{array}$ & 10.9543 & 10.9645 & 16.0843 \\
\hline \multirow{2}{*}{3} & 3 & $\begin{array}{c}{[83,122,} \\
167]\end{array}$ & $\begin{array}{c}{[83,122,} \\
168]\end{array}$ & $\begin{array}{c}{[99,130,} \\
143]\end{array}$ & 13.4982 & 13.5247 & 15.2643 \\
\hline & 4 & $\begin{array}{l}{[80,116,} \\
152,194]\end{array}$ & $\begin{array}{l}{[80,116,} \\
153,195]\end{array}$ & $\begin{array}{c}{[102,122,} \\
131,144]\end{array}$ & 11.4773 & 11.4954 & 27.236 \\
\hline 4 & 4 & $\begin{array}{c}53,98, \\
136,199]\end{array}$ & $\begin{array}{c}{[54,98,} \\
136,199]\end{array}$ & $\begin{array}{l}{[116,128,} \\
135,249]\end{array}$ & 12.314 & 12.3106 & 19.9752 \\
\hline
\end{tabular}

Berdasarkan tabel di atas, dapat dilihat bahwa nilai threshold yang dihasilkan antara distribusi Gamma dan Gaussian hampir sama. Kemudian, evaluasi dilakukan dengan membandingkan nilai standar deviasi terhadap hasil segmentasi citra yang dihasilkan berdasarkan nilai threshold untuk tiap distribusi yang digunakan dalam pembentukan fuzzy image. Hasil evaluasi terhadap standar deviasi menunjukkan bahwa distribusi Gamma menghasilkan output citra dengan standar deviasi minimum dibandingkan dengan distribusi lainnya.

\subsection{Perbandingan Hasil Segmentasi Citra}

Luka kronis merupakan objek yang sulit untuk dipisahkan, terutama untuk daerah luka dan daerah non-luka. Untuk menguji algoritma yang diusulkan, maka pada sub-bab ini akan dibahas mengenai perbandingan hasil segmentasi citra yang dilakukan pada citra Lena dengan ukuran $512 \times 512$, diterapkan multilevel thresholding untuk memisahkan citra menjadi 5 daerah atau segmen. Perbandingan dilakukan antara algoritma yang diusulkan dengan Otsu-GASA (Genetic Algorithm Simulated Annealing) [12] dan Otsu-EMO (Electromagnetism
Optimization) [20] terhadap citra Lena. Hasil perbandingan segmentasi citra ditunjukkan pada Tabel 3.

Tabel 3. Hasil Segmentasi Citra

\begin{tabular}{|c|c|c|c|}
\hline & Otsu-GASA & Otsu-EMO & Fuzzy Divergence-GA \\
\hline Threshold & {$[74,112,157,186]$} & {$[73,112,144,179]$} & {$[73,111,142,177]$} \\
\hline $\begin{array}{l}\text { Standard } \\
\text { Deviation }\end{array}$ & 10.696 & 9.776 & 9.553 \\
\hline $\begin{array}{l}\text { Citra } \\
\text { Output }\end{array}$ & & & 10 \\
\hline
\end{tabular}

Berdasarkan Tabel 3, dapat dilihat bahwa nilai threshold yang dihasilkan dengan menggunakan algoritma fuzzy divergence-GA menghasilkan citra output dengan standar deviasi minimum dibandingkan dengan metode pembanding. Jadi, dapat disimpulkan bahwa secara umum algoritma yang diusulkan dapat digunakan untuk mengoptimasi model segmentasi citra multilevel thresholding dengan meminimalkan nilai fuzzy divergence.

\section{KESIMPULAN}

Berdasarkan hasil pengujian dan analisis dari implementasi algoritma genetika untuk optimasi model segmentasi citra metode fuzzy divergence pada citra luka kronis, maka disimpulkan bahwa algoritma genetika dapat digunakan untuk mengoptimasi model segmentasi citra multilevel thresholding dengan meminimalkan nilai fuzzy divergence. Pengujian algoritma genetika menghasilkan parameter-parameter terbaik yang menghasilkan solusi mendekati optimal. Parameter algoritma genetika, meliputi ukuran populasi sebesar 60, kombinasi ukuran $c r$ dan $m r$ secara berturut-turut 0.6 dan 0.4, dan ukuran generasi sebesar 100 .

Pengujian segmentasi fuzzy divergence menghasilkan model berupa distribusi yang digunakan untuk membentuk fungsi keanggotaan citra atau fuzzy image, yaitu distribusi Gamma. Hasil segmentasi citra fuzzy divergence masih terlihat kurang baik dalam penggolongan komposisi jaringan luka pada luka kronis. Hal ini disebabkan, luka kronis merupakan objek yang cukup kompleks untuk dipisahkan, terutama untuk daerah luka dan daerah non-luka yang memiliki komposisi warna yang hampir sama. Diperlukan sebuah metode atau 
mekanisme untuk memisahkan daerah luka dan daerah non-luka.

Algoritma yang diusulkan masih perlu dikembangkan lebih lanjut, sehingga dapat lebih baik dalam task pengukuran daerah luka berdasarkan penggolongan komposisi jaringan luka dengan penilaian yang lebih akurat. Terlihat bahwa hasil yang dihasilkan kurang maksimal, karena pada penelitian ini belum diterapkan treatment khusus pada citra sebelum disegmentasi. Untuk penelitian dan pengembangan lebih lanjut, perlu ditambahkan perlakuan atau treatment pada citra. Kemudian, kaitannya dengan penggolongan komposisi jaringan luka, perlu ditambahkan metode atau mekanisme untuk memisahkan daerah luka dan daerah non-luka terlebih dahulu. Pemilihan representasi warna dalam segmentasi citra metode thresholding juga sangat berpengaruh pada hasil segmentasi yang dihasilkan.

\section{DAFTAR PUSTAKA}

Ayala, Helon Vicente H., Santos, Fernando Marins., Mariani, Viviana Cocco., Coelho, Leandro dos Santos. (2015). Image thresholding segmentation based on a novel beta differential evolution approach. I.J.Expert Systems with Applications, 42(4), 2136-2142.

Bhatia, P K., Singh, Surender. (2013). A New Measure of Fuzzy Directed Divergence and Its Application in Image Segmentation. I.J. Intelligent Systems and Applications, 4, 81-89.

Chaira, T., Ray, A K. (2003). Segmentation using fuzzy divergence. Elsevier Pattern Recognition Letters, 24, $1837-1844$.

Fauzi, Muhammad Faizal Ahmad., Khansa, Ibrahim., Catignani, Karen., Gordillo, Gayle., Sen, Chandan K., Gurcan, Metin N. (2015). Computerized segmentation and measurement of chronic wound images. Elsevier Computers in Biology and Medicine, 60, 74-85.

Ghosh, Madhumala., Das, Devkumar., Chakraborty, C., Ray, A K. (2010). Automated leukocyte recognition using fuzzy divergence. Elsevier Micron, 41, 840-846.

Ghosh, Madhumala., Chakraborty, C., Ray, A K. (2013). Yager's measure based fuzzy divergence for microscopic color image segmentation. Indian Conference on Medical Informatics and Telemedicine (ICMIT), 13-16.

Hammouche, Kamal., Diaf, Moussa., Siarry, Patrick. (2008). A multilevel automatic thresholding method based on a genetic algorithm for a fast image segmentation. Elsevier Computer Vision and Image Understanding, 109, 163-175.

Jati, A., Singh, G., Koley, S., Konar, A., Ray, A K., Chakraborty, C. (2015). A novel segmentation approach for noisy medical images using Intuitionistic fuzzy divergence with neighbourhood-based membership function. Journal of Microscopy, 257(3), 187-200.

Mahmudy, W.F. (2014). Optimisation of Integrated MultiPeriod Production Planning and Scheduling Problems in Flexible Manufacturing Systems (FMS) Using Hybrid Genetic Algorithms, School of Engineering, University of South Australia.

Mahmudy, WF, Marian, RM \& Luong, LHS. (2013). Modeling and optimization of part type selection and loading problems in flexible manufacturing system using real coded genetic algorithms. International Journal of Electrical, Computer, Electronics and Communication Engineering, 7(4), 251-260.

Mahmudy, WF \& Rahman, MA (2011), Optimasi fungsi multi-obyektif berkendala menggunakan algoritma genetika adaptif dengan pengkodean real, Kursor, vol. 6, no. 1, pp. 19-26.

Manikandan, S., Ramar, K., Iruthayarajan, M W., Srinivasagan, K G. (2013). Multilevel thresholding for segmentation of medical brain images using Real coded Genetic Algorithm. Elsevier Measurement.

Mukherjee, Rashmi., Manohar, Dhiraj D., Das, Devkumar., Achar, Arun., Mitra, Analava., Chakraborty, C. (2014). Automated Tissue Classification Framework for Reproducible Chronic Wound Assessment. Hindawi BioMed Research International, 2014, 1-9.

Muppidi, Mohan., Rad, Paul., Agaian, Sos S., Jamshidi, Mo. (2015). Image Segmentation by Multi-Level Thresholding Based on Fuzzy Entropy and Genetic Algorithm in Cloud. IEEE System of Systems Engineering Conference (SoSE), 492-497.

Muppidi, Mohan., Rad, Paul., Agaian, Sos S., Jamshidi, Mo. (2015). Image Segmentation by Multi-Level Thresholding Using Genetic Algorithm with Fuzzy Entropy Cost Functions. IEEE Image Processing Theory, Tools and Applications, 143-148.

Oliva, Diego., Cuevas Erik., Pajares, Gonzalo., Zaldiar, Daniel., Osuna, Valentin. (2014). A Multilevel Thresholding algorithm using electromagnetism optimization. Elsevier Neurocomputing, 139, 357-381.

Pare, S., Bhandari A. K., Kumar, A., Singh, G. K., Khare, S. (2015). Satellite Image Segmentation based on Different Objective Functions using genetic algorithm: A Comparative Study. IEEE, 730-734.

Putra, Darma. 2010. Pengolahan Citra Digital. Yogyakarta: ANDI.

Putra, I K G D., Suarjana, I Gede. (2010). Segmentasi Citra Retina Digital Etinopati Diabetes Untuk Membantu Pendeteksian Mikroaneurisma. Jurnal Teknologi Elektro, 9(1), 44-49.

Ren, Xiaobing. (2009). An Optimal Image Thresholding using Genetic Algorithm. IEEE International Forum on Computer Science-Technology and Applications, 169-172.

Salavati, A A H., Mozafari, Saeed. (2015). Provide a hybrid method to improve the performance of multilevel thresholding for image segmentation using $\mathrm{GA}$ and $\mathrm{SA}$ algorithms. IEEE International Conference on Information and Knowledge Technology.

Sridevi, M., Mala, C., Sivasankar, E., You, Ilsun. (2014). Optimized Multilevel Threshold Selection using Evolutionary Computing. International Conference on Network-Based Information Systems, 149-156.

Wei, Jiang Hua., Kai, Yang. (2010). Research of Improved Genetic Algorithm for Thresholding Image Segmentation Based on Maximum Entropy. IEEE, 619-622.

Wijayaningrum, VN \& Mahmudy, WF (2016), Optimization of Ship's Route Scheduling Using Genetic Algorithm, Indonesian Journal of Electrical Engineering and Computer Science, vol. 2, no. 1, pp. 180-186.

Zhou, H., Wu, J., Zhang, J. 2010. Digital Image Processing: Part I. Ventus Publishing Aps. 